\title{
Use of plant extracts from healthy soybean and potato plants for treatments of plants of the same species
}

Uso de extratos vegetais advindos de plantas sadias de soja e batata para tratamentos de plantas de mesma espécie

Utilización de extractos vegetales de plantas sanas de soja y patata para tratamientos de plantas de la misma especie

\begin{abstract}
The present study proposes to evaluate extracts from shoots of healthy soybean and potato plants for the treatment of plants of the same species cultivated subsequently. Two experiments were thus conducted separately after the soybean and potato inoculum production phases. For soybean, the experiment was laid out in a randomized-block design with five treatments and four replications, in which the following treatments were tested: 1. absolute control without inoculum or pesticides; 2. farmer management with pesticides, without inoculum; 3. use of inoculum, without insecticides; 4. use of inoculum, without fungicides; and 5. use of inoculum, without pesticides. In the soybean crop, the tested inoculum improved plant development and, increased the potassium content of the plant tissue as well as yield. For the potato crop, a randomized-block statistical design was adopted with two treatments and ten replications, using varieties Ágata and Atlantic. The following treatments were tested: 1. absolute control without inoculum, with
\end{abstract}


pesticides; and 2. use of inoculum (foliar spraying), with pesticides. With the use of inoculum, varieties Ágata and Atlantic showed distinct responses regarding disease incidence and yield. Late blight was the disease that most affected both varieties, but only Atlantic showed a reduction in its incidence when the inoculum was applied. Variety Atlantic also exhibited an increase in the most valued commercial calibers, besides an increase in yield, with the use of the tested inoculum. Cultivar Ágata showed a marked reduction in tuber defects with the use of the inoculum on the plants.

Keywords: Inoculum; Yield; Diseases; Seed treatment; Foliar spraying.

\title{
Resumo
}

O presente estudo se propõe a avaliar extratos de brotações de plantas hígidas de soja e batata para o tratamento de plantas da mesma espécie cultivadas posteriormente. Dois experimentos foram conduzidos separadamente após as fases de produção de inoculo de soja e batata. Para a soja, o experimento foi delineado em blocos casualizados com cinco tratamentos e quatro repetições, nos quais foram testados os seguintes tratamentos: 1. controle absoluto sem inóculo ou agrotóxicos; 2. manejo do agricultor com agrotóxicos, sem inóculo; 3. uso de inóculo, sem inseticidas; 4. uso de inóculo, sem fungicidas; e 5. uso de inóculo, sem agrotóxicos. Na cultura da soja, o inóculo testado melhorou o desenvolvimento da planta e aumentou o teor de potássio do tecido vegetal, bem como a produtividade. Para a cultura da batata, foi adotado o delineamento estatístico de blocos ao acaso com dois tratamentos e dez repetições, utilizando as variedades Ágata e Atlantic. Foram testados os seguintes tratamentos: 1. controle absoluto sem inóculo, com agrotóxicos; e 2. uso de inóculo (pulverização foliar), com agrotóxicos. Com o uso do inóculo, as variedades Ágata e Atlantic apresentaram respostas distintas quanto à incidência e produtividade da doença. A requeima foi a doença que mais afetou as duas variedades, mas apenas a Atlantic apresentou redução de sua incidência na aplicação do inóculo. A variedade Atlantic também apresentou aumento nos calibres comerciais mais valorizados, além de aumento no rendimento, com a utilização do inóculo testado. A cultivar Ágata apresentou acentuada redução dos defeitos tuberosos com o uso do inóculo nas plantas.

Palavras-chave: Inoculum; Produção; Doenças; Tratamento de sementes; Pulverização foliar.

\begin{abstract}
o
El presente estudio se propone evaluar extractos de brotes sanos de plantas de soja y papa para el tratamiento de plantas de la misma especie cultivadas posteriormente. Se llevaron a cabo dos experimentos por separado después de las fases de producción de inóculo de soja y papa. Para la soja, el experimento se diseñó en bloques al azar con cinco tratamientos y cuatro repeticiones, en los que se probaron los siguientes tratamientos: 1. control absoluto sin inóculo ni pesticidas; 2. manejo de agricultores con plaguicidas, sin inóculo; 3. uso de inóculo, sin insecticidas; 4. uso de inóculo, sin fungicidas; y 5. uso de inóculo, sin pesticidas. En el cultivo de soja, el inóculo probado mejoró el desarrollo de la planta y aumentó el contenido de potasio del tejido vegetal, así como la productividad. Para el cultivo de papa se adoptó un diseño estadístico de bloques al azar con dos tratamientos y diez repeticiones, utilizando las variedades Ágata y Atlantic. Se probaron los siguientes tratamientos: 1. control absoluto sin inóculo, con plaguicidas; y 2. uso de inóculo (aspersión foliar), con plaguicidas. Con el uso del inóculo, las variedades Ágata y Atlantic mostraron diferentes respuestas en cuanto a la incidencia y productividad de la enfermedad. El tizón tardío fue la enfermedad que más afectó a ambas variedades, pero solo Atlantic mostró una reducción en su incidencia en la aplicación del inóculo. La variedad atlántica también mostró un aumento en los calibres comerciales más valorados, además de un aumento en el rendimiento, con el uso del inóculo ensayado. El cultivar Ágata mostró una marcada reducción de los defectos tuberosos con el uso de inóculo en las plantas.
\end{abstract}

Palabras clave: Inóculo; Producción; Enfermedades; Tratamiento de semillas; Spray foliar.

\section{Introduction}

In the soybean crop, achieving high yields entails applied knowledge and cultivation practices as well as observing the logic of plant development and the basic principles of plant physiology.

Soybean is the grain crop with the largest cultivated area in Brazil. In recent years, its yield has risen as a result of the use of new technologies and the growing professionalization of rural producers (Trentin et al., 2013). To increase yield, soybean farmers adopt several management alternatives (Oliveira et al., 2017). The growing production rates of Brazilian soybean are related to scientific advances and the use of technologies in the production sector, one of which is the application of fertilizers and biostimulants (Balen et al., 2015).

Potato (Solanum tuberosum L.) is considered the main vegetable both in cultivated area and food preference (Filgueira, 2008). Despite its high productivity, the potato crop is affected by approximately 70 diseases caused by different pathogens, including fungi and bacteria, which impact its yield. Disease management in this crop must be based on 
multidisciplinary programs, which integrate different strategies, with the aims of optimizing control, reducing production costs, lessening the environmental impact and improving the quality of life of producers and consumers (Töfoli et al., 2019). The use of biological products can be adopted in organic systems and integrated control programs.

Biological control is achieved by reducing the intensity of inocula or the capacity of a pathogen to induce disease in the target pathogen, through antagonistic interactions such as antibiosis, competition and parasitism. In addition to these antagonistic interactions, microorganisms capable of activating natural plant defense mechanisms are also the subject of biological control studies. The use of biological agents such as endophytic bacteria, plant growth-promoting rhizobacteria (PGPR) and arbuscular mycorrhizal fungus (AMF) has been widely exploited (Kaminsky et al., 2019). The isolation and application of these microbes have been shown to successfully improve agricultural results. According to Sturz (1995), approximately $10 \%$ of the endophytic bacteria isolated from potato tubers promoted plant growth. Growth-promoting effects include increases in the height; shoot, stem and root biomass; and yield of the potato tuber (Pillay \& Nowak, 1997; Sturz, 1995). The main mechanisms by which PGPR and endophytic bacteria promote plant growth are nitrogen fixation (Boddey \& Dobereiner, 1995) and biological control of phytopathogens, which result in increased crop yields (Hay at et al., 2010).

However, inocula, which can be composed of only one or a few microorganisms, are difficult to establish in the field due to soil properties and competition with native microorganisms that are already adapted to the environmental conditions. The solution to this problem may lie in the use of indigenous microorganisms, that is, a group of native microorganisms that inhabit the internal and external tissues of plants, as well as local soils (Qiu et al., 2019). Recent studies suggest that the use of plant microbiome (defined as all microorganisms and their genomes) may be an adequate alternative to alter plant development, reduce abiotic stress and increase the crop's tolerance to diseases (May et al., 2021; Qiu et al., 2019). In this respect, we can highlight the technique of microbial transplantation in agriculture, widely studied in humans (Li et al., 2016), and the restoration of ecosystems (Wubs et al., 2016).

In view of the above-described scenario, the present study proposes to evaluate extracts from shoots of healthy soybean and potato plants for the treatment of plants of the same species cultivated subsequently, to investigate their productive behavior and the incidence of phytosanitary problems.

\section{Methodology}

The study was conducted in two phases: the first was developed to produce plant extracts/inocula from healthy soybean and potato plants, and the second to evaluate the produced extracts/inocula on the soybean and potato crops, following the methodology proposed by May et al. (2021). Two experiments were thus carried out: one with the soybean crop in São Gabriel do Oeste/MS, Brazil, and the other with the potato crop in Palmeira/PR, Brazil, using the same plant extract production process for each crop, respectively, according to the methodology presented below (Phase 1).

\section{Phase 1: Building the clonal garden}

Soil was collected from Castro/PR (S-CA), after the harvest of soybean, to build a clonal garden to cultivate healthy soybean plants; and from Itapetininga/SP (S-IT), after the harvest of potato, to build a clonal garden to cultivate healthy potato plants (Table 1). 'Healthy' soybean and potato plants are defined here as those grown under environmental control, in pots, with no incidence of diseases or pests during the development cycle. The aim was to produce fresh mass from these plants for phase 2 of this study. In each soil collection, the fields were selected according to their history of soybean and potato yields, by choosing the area with the highest crop yield of each farm. These areas were free of phytosanitary problems, according to previous crop management reports. The soil from Castro/PR was collected from a farm that adopted no-tillage for more than 40 years, with various species in crop rotation (e.g. soybean, maize, wheat and oat) and annual application of organic waste 
such as pig manure. The Itapetininga/SP soil was collected from a specialized potato farm that performs crop rotation in the potato-grown plots with other crops such as soybean, wheat and corn, resuming potato growing in the same plot only four years after the previous cycle with the same species.

In total, 35 soil samples were collected in a zigzag pattern from a 10-ha area, from both the municipalities Castro and Itapetininga. Each sample corresponded to approximately $3 \mathrm{~kg}$ of soil from the $0-0.20 \mathrm{~m}$ soil layer. Before collection, the mulch above the soil layer was discarded. The samples of each soil were then mixed to obtain homogeneous soil to fill plastic pots $(0.20 \mathrm{~m}$ high $\times 0.16 \mathrm{~m}$ wide) with approximately $5 \mathrm{~kg}$ of soil per pot for building the clonal garden at the Brazilian Agricultural Research Corporation (Embrapa Environment), in Jaguariúna/SP. In phase 1, the soybean or potato was trained in pots aiming at maximum environmental control of each plant individually, for each soil type collected from the aforementioned productive areas. The irrigation management consisted of frequent irrigation with a drip system, aiming to meet the water requirements of the crop.

\section{Phase 1: Extract production}

Soybean cultivar M5917 IPRO and potato cultivar Ágata were sown or planted on August 2020, using three seeds/minitubers per pot, in a clonal garden at Embrapa Environment. The soybean seeds were inoculated with Bradyrhizobium japonicum $\left(10^{9}\right.$ viable cells $/ \mathrm{kg}$ of seed). The greenhouse was controlled with temperature set to $28^{\circ} \mathrm{C}$ (day) and $19{ }^{\circ} \mathrm{C}$ (night) and a 12-h photoperiod. The soybean and potato plants were collected to make the extracts after 60 days of sowing or planting. The extracts were produced with material collected from above-ground biomass for each species separately.

The collected materials were cleaned by immersion in a solution of $2 \%$ sodium hypochlorite and $0.1 \%$ polyethylene glycol sorbitan monolaurate, and later in sterile water. Then, they were then ground in a knife mill to obtain particles of $0.5 \mathrm{~cm}$ in length. Subsequently, a 1\% polyvinylpyrrolidone (PVP) stabilizing solution was applied to the ground mass. The materials were then pressed in a hydraulic press at a pressure of $15 \mathrm{t} \mathrm{cm}^{-2}$ and the fluid resulting from pressing was centrifuged at 7,000 rpm for $10 \mathrm{~min}$ to collect the microbial precipitate. The microbial precipitates were stored in cryoprotectant solution (20\% glycerol) at $-80^{\circ} \mathrm{C}$ for further use. After these processes, the produced and frozen extracts were freeze-dried for later use.

\section{Phase 2: Experiment 1 - Soybean crop}

After the extract production phase, an experiment was established with the soybean crop on a farm located on Rodovia Estrada Velha km 8, in the municipality of São Gabriel do Oeste/MS (19²7'36.29" S and 54 '36'55.69", 662 m above sea level), from November 17, 2020, to March 13, 2021, making a cycle of 116 days.

The experiment was laid out in a randomized-block design with five treatments and four replications. Each experimental unit consisted of six 9-m-long rows spaced $0.5 \mathrm{~m}$ apart. The two central rows and the four central meters of each of the two rows were considered the usable area of the plot.

The inoculum derived from healthy soybean plants was applied in treatments 3, 4 and 5 (Table 1). 
Table 1. Evaluated treatments and inoculum rates used for the soybean crop.

$\begin{array}{lll}\text { Treatment } & \text { Treatment description } & \text { Inoculum rate } \\ & \end{array}$

\begin{tabular}{|c|c|c|c|}
\hline 1 & Absolute control & No inoculum or pesticide & \\
\hline 2 & Local producer's standard & $\begin{array}{l}\text { Conventional chemical seed treatment }+ \\
\text { Conventional chemical insecticides and } \\
\text { fungicides }\end{array}$ & - \\
\hline 3 & $\begin{array}{l}\text { With inoculum and without } \\
\text { insecticides during the crop } \\
\text { cycle }\end{array}$ & $\begin{array}{l}\text { Inoculum applied in seed treatment and in three } \\
\text { foliar applications, without the use of } \\
\text { insecticides throughout the cycle, only } \\
\text { fungicides }\end{array}$ & $\begin{array}{l}10 \mathrm{mg} \mathrm{kg} \mathrm{seed}^{-1} \text { and } 5 \mathrm{~kg} \\
\text { ha }^{-1} \text { foliarly }\end{array}$ \\
\hline 4 & $\begin{array}{l}\text { With inoculum and without } \\
\text { fungicides during the crop } \\
\text { cycle }\end{array}$ & $\begin{array}{l}\text { Inoculum applied in seed treatment and in three } \\
\text { foliar applications, without the use of fungicides } \\
\text { throughout the cycle, only insecticides }\end{array}$ & $\begin{array}{l}10 \mathrm{mg} \mathrm{kg} \mathrm{seed}^{-1} \text { and } 5 \mathrm{~kg} \\
\text { ha }^{-1} \text { foliarly }\end{array}$ \\
\hline 5 & $\begin{array}{l}\text { With inoculum and without } \\
\text { insecticides or fungicides } \\
\text { during the crop cycle }\end{array}$ & $\begin{array}{l}\text { Inoculum applied in seed treatment and in three } \\
\text { foliar applications, without the use of } \\
\text { insecticides or fungicides }\end{array}$ & $\begin{array}{l}10 \mathrm{mg} \mathrm{kg} \mathrm{seed}^{-1} \text { and } 5 \mathrm{~kg} \\
\text { ha }^{-1} \text { foliarly }\end{array}$ \\
\hline
\end{tabular}

Note: Treatment 2 ("Standard"), followed the standard management for chemical applications.

Seed treatment in treatment 2: Standak Top + Cruiser, $2 \mathrm{~mL}+2 \mathrm{~mL} \mathrm{~kg} \mathrm{seed}^{-1}$.

${ }^{1}$ Volume of mixture used: $200 \mathrm{~L} \mathrm{ha}^{-1}$

Source: Authors.

Soybean cultivar BMX FOCO IPRO was planted on 11/17/2020, using a six-row vacuum seeder, with $0.5 \mathrm{~m}$ spacing between rows, in a no-tillage area. According to the chemical and physical analysis of the soil, the area was classified as dystric Red Ferralsol with smooth-undulated relief, Cerrado phase and clayey texture.

Based on soil analysis and the recommendations for the use of correctives and fertilizers in the state of Mato Grosso do Sul, $190 \mathrm{~kg} \mathrm{ha}^{-1}$ of the $09-46-00+8 \mathrm{~S}$ formulation and $170 \mathrm{~kg} \mathrm{ha}^{-1}$ of the $00-00-60$ fertilizer were broadcast-applied at planting.

During the establishment of the soybean crop, weeds, pests and diseases were managed as recommended for the soybean crop, aiming at high yields, according to the studied treatments (Table 1).

Table 2 shows the products and rates used in the phytosanitary management during the experiment. 
Table 2. Description of applications, products, rates and application dates used for the phytosanitary management of the soybean crop during the experiment. São Gabriel do Oeste/MS, 2021.

\begin{tabular}{|c|c|c|c|}
\hline Application & Product (A.I. ${ }^{1}$ ) & $\begin{array}{c}\text { Rate } \\
\left(\mathrm{g} \text { a.i. or } \mathrm{L} \mathrm{ha} \mathrm{h}^{-1}\right)^{2}\end{array}$ & Date \\
\hline Desiccation & $2,4-\mathrm{D}+$ glyphosate + clethodim + adjuvant ${ }^{3}$ & $480+240+48$ & $10 / 23 / 2020$ \\
\hline Insecticide & Chlorpyrifos & 0.8 & $12 / 01 / 2020$ \\
\hline Fungicide & Propiconazole + difenoconazole + adjuvant & $0.25+0.15$ & $12 / 30 / 2020$ \\
\hline Insecticide & Chlorpyrifos + methoxyfenozide & $0.5+1$ & $12 / 30 / 2020$ \\
\hline Fungicide & $\begin{array}{c}\text { Azoxystrobin }+ \text { benzovindiflupyr }+ \\
\text { Metominostrobin }+ \text { tebuconazole }+ \text { adjuvant }\end{array}$ & $0.65+0.2$ & $01 / 12 / 2021$ \\
\hline Insecticide & Thiamethoxam + lambda-cyhalothrin & $0.25+0.25$ & $01 / 12 / 2021$ \\
\hline Fungicide & $\begin{array}{c}\text { Azoxystrobin }+ \text { benzovindiflupyr }+ \text { chlorothalonil }+ \\
\text { adjuvant }\end{array}$ & $0.2+0.35$ & $01 / 27 / 2021$ \\
\hline Insecticide & Thiamethoxam + lambda-cyhalothrin & $1.2+0.2$ & $01 / 27 / 2021$ \\
\hline Fungicide & $\begin{array}{c}\text { Azoxystrobin }+ \text { benzovindiflupyr }+ \\
\text { metominostrobin }+ \text { tebuconazole }+ \text { adjuvant }\end{array}$ & $0.2+0.65$ & $02 / 11 / 2021$ \\
\hline Insecticide & Thiamethoxam + lambda-cyhalothrin & $0.2+0.3$ & $02 / 11 / 2021$ \\
\hline
\end{tabular}

${ }^{1}$ A.I.: active ingredient; ${ }^{2} \mathrm{~g}$ a.i. ha ${ }^{-1}$ : gram of active ingredient per hectare; ${ }^{3}$ Phosphoric acid alkyl ester ethoxylate. Source: Authors.

All products were applied separately. There was no mixing of products. Applications were performed manually with $\mathrm{CO}_{2}$, following all safety criteria. Insecticides, fungicides or a mixture of the two were applied incisively only as seen fit to the treatments involving chemical management. For the treatments where the inoculum was used, the same criterion for application was adopted.

The following characteristics were evaluated in the studied treatments: initial plant stand: count of plants in $3 \mathrm{~m}$ in the two central rows; final plant stand: count of plants in $3 \mathrm{~m}$ in the two central rows; plant height at R1 and R8: measured using a ruler and/or measuring tape from the soil surface to leaf +1 ; shoot weight: collection of plants at the V6 vegetative stage; root weight: collection of plants at the V6 vegetative stage; pods per plant: count of pods per plant; grains per pod: separation of the grains from the pods; grains per plant: multiplication of the average number of grains per pod by the number of pods per plant; 1000-grain weight (HGW): count of 1000 grains after harvest; yield: harvest from two 5-m central rows (the grains were weighed and moisture was corrected to $13 \%$ ); and seed analysis: samples of $0.500 \mathrm{~kg}$ were separated from each plot for nutritional and chemical analysis.

The data obtained from the evaluations were subjected to analysis of variance and means were compared by Tukey's test $(\mathrm{p}<0.05)$ using AgroEstat software.

\section{Phase 2: Experiment 2 - Potato crop}

After extract production phase 1, an experiment was carried out with the potato crop at the Agricultural Experimental Station of Campos Gerais - EEACG, in the 2020/2021 crop, in the municipality of Palmeira/PR (25 $25^{\prime} 45.08^{\prime \prime} \mathrm{S}$ and $50^{\circ} 03^{\prime}$ 18.73" W, $821 \mathrm{~m}$ above sea level).

A randomized-block statistical design was adopted with two treatments and ten replications, using varieties Ágata and Atlantic. The treatments were as follows: 1- Control; 2- Inoculum (three applications) (Table 4). 
Varieties Ágata and Atlantic were planted on 11/21/2020, with a spacing of $0.8 \mathrm{~m}$ between rows and using four seeds per linear meter.

Cultivation treatments consisted of fertilization and applications of herbicides, fungicides and insecticides, according to the crop requirements (Aguiar et al., 2014). The soil where the experiment was conducted is classified as a Cambisol, whose predecessor crop was white oat. The crop was implemented in an area prepared using a rotary hoe. Emergence occurred on 12/3/2020 and earthing up was performed on 12/10/2020. Table 3 describes the other agricultural practices performed.

Table 3. Agricultural practices performed during the experiment. Palmeira/PR. 2020-2021 crop.

\begin{tabular}{|c|c|c|c|c|c|}
\hline \multicolumn{6}{|l|}{ Furrow treatment: } \\
\hline Trade name & Technical name & & Rate & Unit & Date \\
\hline Regent $800 \mathrm{WG}$ & Fipronil & & 0.15 & $\mathrm{~kg} \mathrm{ha}^{-1}$ & $11 / 21 / 20$ \\
\hline Kasumin & Kasugamycin & & 0.2 & $\mathrm{~L} / 100 \mathrm{~L}$ & $11 / 21 / 20$ \\
\hline \multicolumn{6}{|l|}{ Fertilization } \\
\hline Type & Fertilizer & Rate & Unit & Formulation & Date \\
\hline \multirow{2}{*}{ Base fertilization } & NPK Organomineral & 3500 & $\mathrm{~kg} \mathrm{ha}^{-1}$ & 04-16-08 & $11 / 21 / 20$ \\
\hline & HF Granulado* & 3500 & $\mathrm{~kg} \mathrm{ha}^{-1}$ & & $11 / 21 / 20$ \\
\hline \multicolumn{6}{|l|}{ Pest management: } \\
\hline Trade name & Technical name & Rate & Unit & Adjuvant & Date \\
\hline Connect & Imidacloprid + beta-cyfluthrin & 0.75 & $\mathrm{~L} \mathrm{ha}^{-1}$ & - & $01 / 08 / 21$ \\
\hline \multicolumn{6}{|c|}{ Disease management: } \\
\hline Trade name & Technical name & Rate & Unit & Adjuvant & Date \\
\hline Curzate & Cymoxanil + Mancozeb & 2.0 & $\mathrm{~kg} \mathrm{ha}^{-1}$ & - & $\begin{array}{l}01 / 08 / 21 \\
01 / 22 / 21\end{array}$ \\
\hline Zetanil & Chlorothalonil + Cymoxanil & 3.0 & $\mathrm{~L} \mathrm{ha}^{-1}$ & $0.2 \mathrm{~L} \mathrm{ha}^{-1}$ Nimbus & $\begin{array}{l}01 / 16 / 21 \\
02 / 01 / 21\end{array}$ \\
\hline \multicolumn{6}{|l|}{ Weed management } \\
\hline Trade name & Technical name & Rate & Unit & Adjuvant & $\overline{\text { Date }}$ \\
\hline Sencor 480 & Metribuzin & 1.5 & $\mathrm{~L} \mathrm{ha}^{-1}$ & - & $12 / 10 / 20$ \\
\hline Poquer & Clethodim & 0.45 & $\mathrm{~L} \mathrm{ha}^{-1}$ & Dash $0.5 \mathrm{~L} \mathrm{ha}^{-1}$ & $12 / 21 / 20$ \\
\hline
\end{tabular}

* HF Granulado: $\mathrm{SiO}_{2} 20 \%$; $\mathrm{MgO} 17 \% ; \mathrm{P}_{2} \mathrm{O}_{5} 3 \% ; \mathrm{CaO} 1.7 \%$; $\mathrm{SO}_{3} 2.5 \% ; \mathrm{K}_{2} \mathrm{O} 2.0 \%$. Source: Authors.

Table 4 describes the treatments evaluated in this experiment as well as mixture rates and volumes. 
Table 4. Description of the treatments. Palmeira/PR. 2020 crop.

\begin{tabular}{|c|c|c|c|}
\hline \multirow{2}{*}{ Treatment } & \multicolumn{2}{|c|}{$\begin{array}{c}\text { Foliar application of } \\
\text { inoculum }\end{array}$} & \multirow{2}{*}{ Concentration $(\mathrm{g} / \mathrm{L}$ of mixture $)$} \\
\hline & $\begin{array}{l}\text { Application } \\
\text { date }\end{array}$ & $\begin{array}{l}\text { Mixture } \\
\text { volume } \\
\left(\mathrm{L} \mathrm{ha}^{-1}\right)\end{array}$ & \\
\hline $1 \quad$ Control & - & - & - \\
\hline \multirow[t]{3}{*}{$2 \quad$ Inoculum } & $12 / 18 / 2021$ & 80 & 6 \\
\hline & $01 / 04 / 2021$ & 130 & 6 \\
\hline & $01 / 22 / 2021$ & 250 & 6 \\
\hline
\end{tabular}

Source: Authors.

The inoculum was applied three times, the first being on 12/18/2020, with both varieties at the BBCH 15 stage, approximately eight days after earthing up. The second application occurred on 01/04/2021, seventeen days after the first, with both varieties at the BBCH 37/61 stage, and the last took place on 01/22/2021, eighteen days after the second application, with the crop at the BBCH 43/49 stage for variety Ágata and at BBCH 45/71 for variety Atlantic.

The products were sprayed using precision-spraying equipment for agronomic tests pressurized with $\mathrm{CO}_{2}$, with an $\mathrm{XR}$ 11002 fan nozzle. The mixture solution volume varied according to the time of application (Table 4), with a pressure constant of $35 \mathrm{lb} / \mathrm{in}^{2}$.

Disease occurrence in each treatment was measured on 01/06/2021,01/13/2021 and 01/22/2021, by evaluating the incidence in 24 plants per sampled point and also assigning scores from 0 to 5 , where $0=$ absence of disease and $5=$ high incidence.

Yield was evaluated by harvesting $4.8 \mathrm{~m}^{2}$ (two 3.0-m rows) per plot on 02/08/2021 and transforming the data into kilograms per hectare. On the same day of harvest, the tubers were classified according to size (classes I and V) and defects (severe, mild and variable), with data expressed in kilograms per hectare.

Results were subjected to analysis of variance by the F test. When significant, the difference between means was compared by Tukey's test at the 5\% probability level, using Sasm - agri software (Canteri et al., 2001).

\section{Results and Discussion}

\section{Phase 2: Experiment 2 - Soybean crop}

There was no significant difference for the initial and final plant stand, root fresh weight or shoot fresh weight (Table 5). The plant population decreased by approximately $14 \%$ in all treatments. Treatments 3,4 and 5 provided better numerical results in terms of root and shoot weight than treatments 1 and 2. 
Table 5. Initial and final plant stands, root fresh weight and shoot fresh weight as a function of the application of foliar products.

\begin{tabular}{ccccc}
\hline \multirow{2}{*}{ Treatment } & Initial stand & Final stand & $\begin{array}{c}\text { Root } \\
\text { weight }\end{array}$ & Shoot weight \\
\cline { 2 - 5 } & Plants ha $^{-1}$ & Plants ha $^{-1}$ & $\mathrm{~g}$ \\
\hline 1 & 306,818 & 269,866 & 7.13 & 45.50 \\
2 & 301,704 & 266,033 & 8.13 & 51.65 \\
3 & 309,886 & 268,333 & 8.81 & 52.89 \\
4 & 298,636 & 265,266 & 9.70 & 56.37 \\
\hline F test & 304,261 & 267,375 & 9.83 & 55.92 \\
\hline Treatments & & & & \\
CV $(\%)$ & $0.45 \mathrm{~ns}$ & $0.12 \mathrm{~ns}$ & $0.89 \mathrm{~ns}$ & $0.30 \mathrm{~ns}$ \\
LSD & 4.27 & 3.86 & 27.34 & 30.31 \\
Overall mean & 29.308 .66 & 23.316 .73 & 5.37 & 35.84 \\
\hline
\end{tabular}

Source: Authors.

In the analysis of plant height at R1 and R8 (Table 6), treatment 5 showed a significant difference, with taller plants at R1 as compared with treatment 1 . Treatment 5 consisted of inoculum applied in seed treatment and in three foliar applications, without the use of insecticides or fungicides. For the other treatments, there was no significant difference. Plant height at R8 did not differ significantly; however, the plants in all treatments were taller than $100 \mathrm{~cm}$, especially under treatment 3.

May et al. (2021) examined the use of bacterial consortium inocula and found an improvement in the initial development of soybean plants, in an experiment conducted under controlled conditions.

It is known that manipulating the plant microbiome can inhibit the occurrence of plant diseases (Andrews, 1992; Bloemberg \& Lugtenberg, 2001), increase yield (Bakker et al., 2012) and allow a reduction in the need for chemical inputs (Adesemoye et al., 2009; Bell et al., 2011; Bender et al., 2016). 
Table 6. Plant height as a function of foliar product applications in the soybean crop.

\begin{tabular}{ccc}
\hline \multirow{2}{*}{ Treatment } & Plant height R1 & Plant height R8 \\
\cline { 2 - 3 } & $\mathrm{cm}$ & $\mathrm{cm}$ \\
\hline 1 & $0.64 \mathrm{~b}$ & 110.30 \\
2 & $0.68 \mathrm{ab}$ & 111.87 \\
3 & $0.67 \mathrm{ab}$ & 113.25 \\
4 & $0.66 \mathrm{ab}$ & 109.00 \\
5 & $0.70 \mathrm{a}$ & 111.10 \\
\hline F test ${ }^{1}$ & & \\
\hline Treatments & $3.52^{*}$ & $0.53 \mathrm{~ns}$ \\
CV $(\%)$ & 3.66 & 3.95 \\
LSD & 0.05 & 0.09 \\
Overall mean & 0.67 & 111.10 \\
\hline
\end{tabular}

Source: Authors.

Table 7 shows the data on number of pods per plant, number of grains per pod, number of grains per plant, thousandgrain weight and yield.

There was a significant difference for yield, for which treatment 3 provided the highest mean, differing statistically from treatments 1 and 2 (Control and Producer standard, respectively). There was no difference for the other treatments inoculated with the bioproduct. Thus, the treatments in which the inoculum was applied (treatments 3,4 and 5) provided better yield results than treatments 1 and 2. According to Mendes et al. (2015), the soybean plant roots select a specific microbial community, with functional characteristics that can benefit the plant, promoting development.

There were no significant differences between the treatments for number of pods per plant, number of grains per pod, number of grains per plant or thousand-grain weight (Table 7).

Table 7. Number of pods per plant, grains per pod and grains per plant, thousand-grain weight (TGW) and yield as a function of foliar product applications in the soybean crop.

\begin{tabular}{cccccc}
\hline \multirow{2}{*}{ Treatment } & Pods plant $^{-1}$ & Grains pod $^{-1}$ & Grains plant $^{-1}$ & TGW & Yield \\
\cline { 2 - 6 } & $\mathrm{n}$ & $\mathrm{n}$ & $\mathrm{n}$ & $\mathrm{g}$ & $\mathrm{kg} \mathrm{ha}^{-1}$ \\
\hline 1 & 46.80 & 2.75 & 128.85 & 148.70 & $4,266.31 \mathrm{~b}$ \\
2 & 47.15 & 2.80 & 124.00 & 150.06 & $4,197.09 \mathrm{~b}$ \\
3 & 47.80 & 2.72 & 130.75 & 156.11 & $4,665.90 \mathrm{a}$ \\
4 & 51.35 & 2.63 & 139.80 & 157.49 & $4,587.45 \mathrm{ab}$ \\
5 & 47.15 & 2.63 & 125.90 & 150.88 & $4,463.10 \mathrm{ab}$ \\
\hline F test & & & & & \\
\hline Treatments & $0.31 \mathrm{~ns}$ & $0.94 \mathrm{~ns}$ & $0.53 \mathrm{~ns}$ & $2.35 \mathrm{~ns}$ & $3.38^{*}$ \\
CV (\%) & 14.15 & 3.81 & 13.01 & 3.33 & 4.94 \\
LSD & 15.33 & 0.23 & 38.08 & 11.46 & 463.27 \\
Overall mean & 48.05 & 2.68 & 129.87 & 152.65 & $4,435.95$ \\
\hline
\end{tabular}

Source: Authors. 
Table 8 shows the results of macronutrient contents in soybean. There was a significant difference for potassium (K), which was higher in treatment 5 than in treatments 1 and 2. According to Bakhshandeh et al. (2020), plant growth-promoting microorganisms can improve germination, seedling growth and $\mathrm{K}$ uptake in soybean. Plant growth-promoting rhizobacteria improve nutrient availability to plants by mobilizing minerals from the soil, providing growth regulators and essential minerals such as potassium and phosphorus (Naik et al., 2019; Tabassum et al., 2017). The production of organic and inorganic acids by microorganisms is the main mechanism of K solubilization (Maurya et al., 2014; Meena et al., 2017; Parmar \& Sindhu, 2013), whereby insoluble $\mathrm{K}$ is converted into soluble form, which is easily absorbed by plants (Hu et al., 2006; Mo \& Lian, 2011).

Table 8. Macronutrient and micronutrient contents in soybean seeds as a function of the treatments studied in the soybean crop.

\begin{tabular}{|c|c|c|c|c|c|c|}
\hline \multirow{2}{*}{ Treatment } & $\mathrm{N}$ & $\mathrm{P}$ & $\mathrm{K}$ & $\mathrm{Ca}$ & $\mathrm{Mg}$ & S \\
\hline & \multicolumn{6}{|c|}{$\mathrm{g} \mathrm{kg}^{-1}$} \\
\hline 1 & 57.62 & 6.35 & $16.95 \mathrm{c}$ & 2.60 & 2.65 & 2.83 \\
\hline 2 & 54.30 & 6.37 & $18.72 \mathrm{bc}$ & 2.44 & 2.67 & 3.00 \\
\hline 3 & 54.05 & 6.58 & $21.19 \mathrm{ab}$ & 2.42 & 2.80 & 3.08 \\
\hline 4 & 56.01 & 6.62 & $20.57 \mathrm{ab}$ & 2.56 & 2.83 & 3.33 \\
\hline 5 & 54.86 & 6.55 & $22.09 \mathrm{a}$ & 2.71 & 2.74 & 3.13 \\
\hline \multicolumn{7}{|l|}{$\mathrm{F}$ test $^{1}$} \\
\hline Treatments & $0.65 \mathrm{~ns}$ & $0.40 \mathrm{~ns}$ & $10.79 * *$ & $0.99 \mathrm{~ns}$ & $1.27 \mathrm{~ns}$ & $3.13 \mathrm{~ns}$ \\
\hline CV $(\%)$ & 6.55 & 6.14 & 6.30 & 9.43 & 5.10 & 6.68 \\
\hline LSD & 8.18 & 0.90 & 2.82 & 0.54 & 0.31 & 0.46 \\
\hline Overall mean & 55.37 & 6.49 & 19.90 & 2.55 & 2.74 & 3.07 \\
\hline \multirow[t]{2}{*}{ Treatment } & $\mathrm{Cu}$ & & $\mathrm{Fe}$ & $\mathrm{Mn}$ & $\mathrm{Zn}$ & B \\
\hline & \multicolumn{6}{|c|}{$\mathrm{mg} \mathrm{kg}^{-1}$} \\
\hline 1 & 17.83 & & 163.56 & 23.86 & 64.42 & $50.98 \mathrm{ab}$ \\
\hline 2 & 17.72 & & 111.62 & 22.92 & 62.40 & $41.52 \mathrm{~b}$ \\
\hline 3 & 21.25 & & 117.94 & 22.81 & 74.01 & $51.68 \mathrm{ab}$ \\
\hline 4 & 21.18 & & 123.33 & 22.85 & 66.94 & $53.34 \mathrm{ab}$ \\
\hline 5 & 21.40 & & 116.58 & 23.34 & 69.49 & $57.60 \mathrm{a}$ \\
\hline \multicolumn{7}{|l|}{$\mathrm{F}$ test $^{1}$} \\
\hline Treatments & $1.43 \mathrm{~ns}$ & & $1.04 \mathrm{~ns}$ & $0.39 \mathrm{~ns}$ & $1.45 \mathrm{~ns}$ & $3.69 *$ \\
\hline $\mathrm{CV}(\%)$ & 16.16 & & 32.61 & 6.14 & 11.15 & 12.03 \\
\hline LSD & 7.24 & & 93.07 & 3.20 & 16.95 & 13.84 \\
\hline Overall mean & 19.87 & & 126.60 & 23.15 & 67.45 & 51.02 \\
\hline
\end{tabular}

Source: Authors. 
The analysis of micronutrient contents (Table 8) revealed a significant difference for the element boron (B) between treatments 1 and 5. Masood et al. (2019) observed that inoculation with Bacillus pumilus in rapeseed increased B uptake, so inoculation is recommended when the soil is deficient in B.

Table 9 shows the mean values for the chemical analysis of the grains sampled in the studied treatments. There was no significant difference for any of the analyzed variables.

Table 9. Chemical analysis of soybean seeds as a function of the treatments studied in the soybean crop.

\begin{tabular}{|c|c|c|c|c|c|c|c|c|}
\hline Treatment & $\mathrm{N}$ & $\mathrm{CP}$ & $\mathrm{ADF}$ & $\mathrm{EE}$ & NDF & DM & MM & TDN \\
\hline & $\mathrm{g} \mathrm{kg}^{-1}$ & $\%$ & $\%$ & $\%$ & $\%$ & $\%$ & $\%$ & $\%$ \\
\hline 1 & 57.62 & 36.01 & 19.96 & 15.65 & 27.89 & 92.62 & 5.19 & 73.86 \\
\hline 2 & 54.30 & 33.93 & 17.12 & 16.58 & 26.70 & 92.30 & 5.04 & 75.85 \\
\hline 3 & 54.05 & 33.78 & 19.08 & 16.13 & 27.58 & 92.95 & 5.26 & 74.48 \\
\hline 4 & 56.01 & 35.01 & 16.61 & 16.18 & 26.62 & 92.93 & 5.22 & 76.20 \\
\hline 5 & 54.86 & 34.28 & 18.29 & 14.98 & 27.10 & 92.94 & 5.18 & 75.03 \\
\hline \multicolumn{9}{|l|}{ F test ${ }^{1}$} \\
\hline Treatments & $0.65 \mathrm{~ns}$ & $0.65 \mathrm{~ns}$ & $1.02 \mathrm{~ns}$ & $0.88 \mathrm{~ns}$ & $0.34 \mathrm{~ns}$ & $0.36 \mathrm{~ns}$ & $0.62 \mathrm{~ns}$ & $1.02 \mathrm{~ns}$ \\
\hline $\mathrm{CV}(\%)$ & 6.55 & 6.55 & 14.96 & 8.19 & 6.90 & 1.01 & 4.02 & 2.54 \\
\hline LSD & 8.18 & 5.11 & 6.14 & 2.93 & 4.22 & 2.13 & 0.47 & 4.30 \\
\hline Overall mean & 55.37 & 34.60 & 18.21 & 15.90 & 27.18 & 92.75 & 5.18 & 75.08 \\
\hline
\end{tabular}

Note: $\mathrm{N}$ - nitrogen; $\mathrm{CP}$ - crude protein; ADF - acid detergent fiber; $\mathrm{EE}$ - ether extract; NDF - neutral detergent fiber; DM - dry matter; MM - mineral matter; TDN - total digestible nutrients. Source: Authors.

\section{Phase 2: Experiment 2 - Potato crop}

The high rainfall in January 2021 (21 consecutive rain days, $373 \mathrm{~mm}$ ) favored the emergence and rapid evolution of diseases in the potato crop, especially late blight and blackleg, for both studied varieties.

On 01/06/2021, with both varieties at the BBCH 37/61 stage, the average score for late blight and blackleg was still low $(<1)$ (Table 10). However, for late blight, a significant increase was observed in the subsequent evaluations, which took place on 01/13/2020 (BBCH 41/63 - Ágata and BBCH 45/65 - Atlantic), but without significant differences between treatments. In the last evaluation, on 01/22/2021 (BBCH 43/69 - Ágata and BBCH 45/71 - Atlantic), the average score for variety Ágata was greater than 3, with no significant differences between the studied treatments. In the case of variety Atlantic, the Control was most affected, reaching an average score of 4.6 and differing from the Inoculum treatment, which showed an average of 2.2. Both studied varieties are considered to be susceptible to late blight (Duarte, 2009). Nonetheless, the greater the microbial diversity of the production environment, the lower the soil invasion by pathogens (Wei et al. 2015; Yang et al. 2016).

For blackleg, scores were equal to or lower than 1.0 during the evaluations of both varieties, without significant differences (Table 10).

The use of biological control in association with other management techniques can be a viable alternative to improve the phytosanitary management of cultivated plants. Many bacterial species present in the rhizosphere, with high functional diversity, prevent infection by Ralstonia solanacearum (Wei et al., 2015). In a similar study on tomato, Irikiin et al. (2006) found that plants inoculated with only a single strain are less protected than plants inoculated with a mixture of 15 bacterial 
strains. In addition, inoculating plants with several bacterial species expressing only one beneficial characteristic of the plant (e.g. nitrogen fixation) does not necessarily result in plant growth, supporting the hypothesis that several microbial functional groups are needed to increase plant biomass (Singh et al., 2015).

Finally, it is known that it is difficult for a single species added as inoculum in the environment to compete with preexisting bacteria in the system, due to their adaptation to the environmental conditions. Thus, one possibility to increase the survival and adaptation of microorganisms added to the system is the use of techniques that allow bacterial consortium or the use of indigenous microorganisms (May et al., 2021). The indigenous community is a group of innate microorganisms that inhabit the inner tissues and outer surfaces of plants (Qiu et al., 2019). Recent studies have demonstrated the benefits of using these communities in increasing plant resistance to biotic/abiotic stresses, suggesting that strains already adapted to the plant environment can increase the chances of the inoculum surviving, exerting a positive effect on plant development (Banerjee et al., 2017; Marulanda et al., 2009).

Table 10. Scoring of disease occurrence in different treatments in potato (S. tuberosum), varieties Ágata and Atlantic. Palmeira/PR, 2020/21 crop.

Disease occurrence (scores from 0 to 5) $\quad$ Disease occurrence (scores from 0 to 5)

$\begin{array}{llll}\text { Treatment } & \text { Variety } & \text { Late blight } & \text { Blackleg }\end{array}$

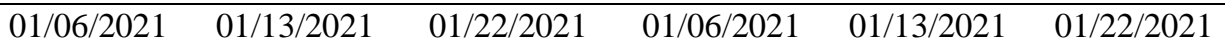

\begin{tabular}{|c|c|c|c|c|c|c|c|c|c|c|c|c|c|c|}
\hline 1 & Control & \multirow{2}{*}{ Ágata } & 0.8 & $\mathrm{a}$ & 2.9 & $\mathrm{a}$ & 3.9 & $\mathrm{a}$ & 0.0 & $\mathrm{a}$ & 0.5 & $\mathrm{a}$ & 1.0 & $\mathrm{a}$ \\
\hline \multirow[t]{3}{*}{2} & Inoculum & & 0.4 & $\mathrm{a}$ & 2.6 & $\mathrm{a}$ & 3.4 & $\mathrm{a}$ & 0.4 & $\mathrm{a}$ & 1.0 & $\mathrm{a}$ & 0.5 & $\mathrm{a}$ \\
\hline & LSD & & 0.60 & & 0.83 & & 1.13 & & 0.91 & & 2.03 & & 2.03 & \\
\hline & $\mathrm{CV}(\%)$ & & 19.78 & & 11.50 & & 12.40 & & 26.03 & & 47.79 & & 47.79 & \\
\hline 1 & Control & \multirow{2}{*}{ Atlantic } & 0.3 & $\mathrm{a}$ & 3.1 & $\mathrm{a}$ & 4.6 & $\mathrm{a}$ & 0.9 & $\mathrm{a}$ & 1.0 & $\mathrm{a}$ & 1.0 & $\mathrm{a}$ \\
\hline \multirow[t]{3}{*}{2} & Inoculum & & 0.3 & $\mathrm{a}$ & 2.7 & $\mathrm{a}$ & 2.2 & $\mathrm{~b}$ & 1.2 & $\mathrm{a}$ & 1.0 & $\mathrm{a}$ & 1.0 & $\mathrm{a}$ \\
\hline & LSD & & 0.34 & & 0.91 & & 0.50 & & 1.79 & & 2.39 & & 2.39 & \\
\hline & CV (\%) & & 12.28 & & 11.88 & & 6.92 & & 40.14 & & 52.97 & & 52.97 & \\
\hline
\end{tabular}

Means followed by the same letter in the column do not differ by Tukey's test at the 5\% probability level. Source: Authors.

In addition to measuring disease incidence through scores, the number of plants with symptoms was also counted (Table 11). For variety Ágata, there were no statistical differences in the evaluations between the Control and Inoculum treatments. Late blight showed a rapid evolution, reaching $15.2 \%$ and $15.3 \%$ of incidence, in the Control and Inoculum treatments, respectively. For variety Atlantic, only in the second evaluation did the inoculum treatment provide a significant reduction in the incidence of plants with late blight relative to the Control; however, in the last evaluation, the treatments were statistically equal. The incidence of blackleg was low in all studied treatments, for both cultivars. 
Table 11. Incidence of diseases in 24 plants of potato (S. tuberosum) varieties Ágata and Atlantic in different treatments. Palmeira/PR, 2020/21 crop.

$\begin{array}{llll}\text { Treatment } & \text { Variety blight } & \text { Blackleg }\end{array}$

$\begin{array}{llllll}01 / 06 / 2021 & 01 / 13 / 2021 & 01 / 22 / 2021 & 01 / 06 / 2021 & 01 / 13 / 2021 & 01 / 22 / 2021\end{array}$

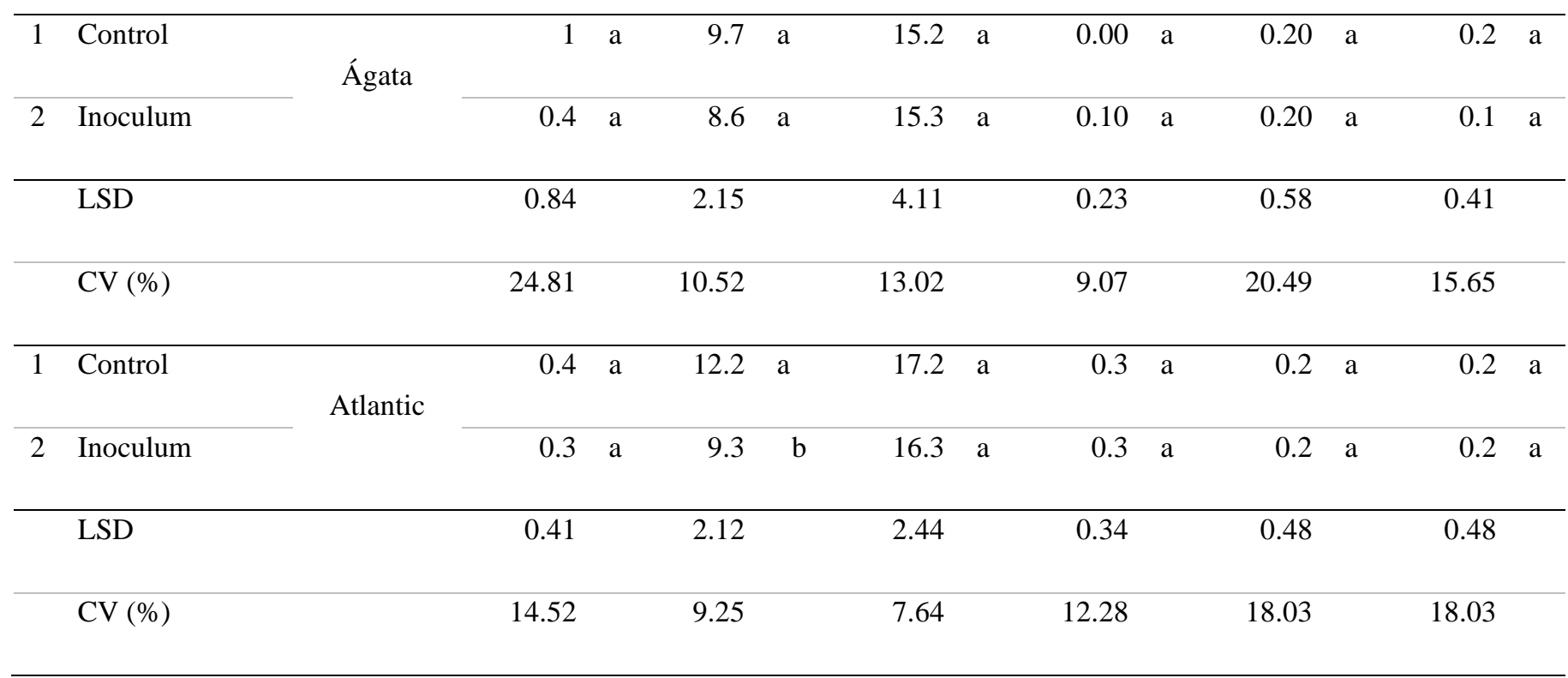

Means followed by the same letter in the column do not differ by Tukey's test at the 5\% probability level. Source: Authors.

Due to the high disease severity, the harvest was advanced, which significantly reduced crop yield. Table 12 shows the results regarding the classification of the tubers according to size.

For potato variety Ágata, the highest yield was concentrated in type-II tubers (> 42 to $70 \mathrm{~mm}$ ), with no significant differences between treatments. However, potatoes with smaller calibers (types IV and V) were observed more frequently in Control treatment, which differed statistically from the Inoculum treatment. Thus, the use of inoculum was able to reduce the tubercles with smaller sizes - types IV and V-by 86.1 and 52.8\%, respectively, in comparison with the uninoculated Control.

For variety Atlantic, most tubers were classified as type I and II. For type II, the Inoculum treatment provided a higher yield (7.6\% statistically higher than Control). No type IV or V size tubers were observed (Table 12). 
Table 12. Potato yield according to size in different treatments, varieties Ágata and Atlantic. Palmeira/PR, 2020/21 crop.

\begin{tabular}{|c|c|c|c|c|c|c|c|}
\hline & \multirow{3}{*}{ Treatment } & \multirow{3}{*}{ Variety } & \multicolumn{5}{|c|}{ Classification according to caliber $\left(\mathrm{kg} \mathrm{ha}^{-1}\right)-02 / 08 / 2021$} \\
\hline & & & TYPE I & TYPE II & TYPE III & TYPE IV & TYPE V \\
\hline & & & $>70 \mathrm{~mm}$ & $>42$ to $70 \mathrm{~mm}$ & $>33$ to $42 \mathrm{~mm}$ & $>28$ to $33 \mathrm{~mm}$ & $<28 \mathrm{~mm}$ \\
\hline 1 & Control & & $3735.5 \quad \mathrm{a}$ & $11655.2 \quad \mathrm{a}$ & $604.2 \quad \mathrm{a}$ & $37.5 \quad \mathrm{a}$ & $39.8 \quad \mathrm{a}$ \\
\hline 2 & Inoculum & . & $4242.7 \quad \mathrm{a}$ & $11646.4 \quad \mathrm{a}$ & $546.4 \quad \mathrm{a}$ & $5.2 \quad b$ & $18.8 \mathrm{~b}$ \\
\hline & LSD & & 511.52 & 3387.49 & 158.18 & 23.18 & 15.21 \\
\hline & $\mathrm{CV}(\%)$ & & 5.70 & 12.92 & 12.22 & 34.83 & 11.04 \\
\hline 1 & Control & & $3054.2 \quad \mathrm{a}$ & $3363.0 \quad \mathrm{~b}$ & $59.4 \quad \mathrm{a}$ & - & - \\
\hline 2 & Inoculum & & $3461.0 \quad \mathrm{a}$ & $3618.2 \quad \mathrm{a}$ & $70.9 \quad \mathrm{a}$ & - & - \\
\hline & LSD & & 513.71 & 169.89 & 67.56 & & \\
\hline & $\mathrm{CV}(\%)$ & & 7.01 & 2.16 & 36.39 & & \\
\hline
\end{tabular}

Means followed by the same letter in the column do not differ by Tukey's test at the 5\% probability level. Source: Authors.

The total yield of variety Ágata was $16032.3 \mathrm{~kg} \mathrm{ha}^{-1}$ in the Control treatment and $16440.7 \mathrm{~kg} \mathrm{ha}^{-1}$ in the Inoculum treatment. Despite the lack of statistical differences between treatments, there was a gain of $2.5 \%$ in the treatment with application of the product. As for defects, Control treatment showed a statistically higher incidence of the severe, mild and variable types, in comparison with the treatment with application of the inoculum. The use of the product on the plants provided reductions of 72,52 and $88 \%$ in the defects of each category, respectively (Table 13).

Variety Atlantic was more affected by rainfall, showing average yields of $6476.6 \mathrm{~kg} \mathrm{ha}^{-1}$ in Control treatment and $7150.0 \mathrm{~kg} \mathrm{ha}^{-1}$ in the treatment with the inoculating product. This represented a relative gain of $9.4 \%$, with statistical differences occurring between the treatments. However, the evaluated defects did not differ significantly between treatments, and variable defects prevailed over the mild and severe types (Table 13). 
Table 13. Potato total yield and classification according to defects in different treatments, varieties Ágata and Atlantic. Palmeira/PR, 2020/21 crop.

Yield (kg/ha) $\quad$ Relative Defects

Treatment $\quad$ Variety $\quad$ TOTAL

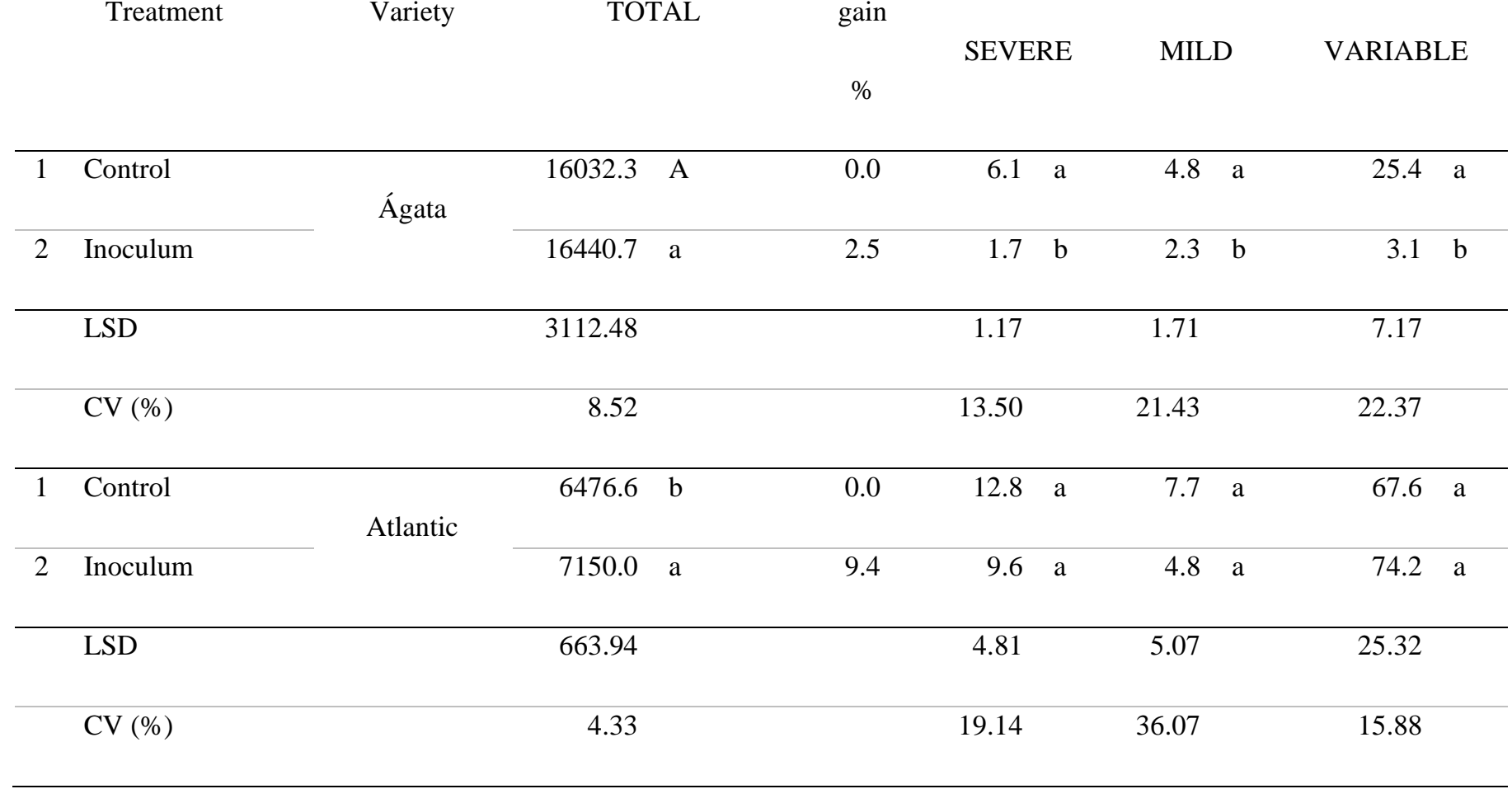

Means followed by the same letter in the column do not differ by Tukey's test at the 5\% probability level. Source: Authors.

\section{Conclusion}

In the soybean crop, the tested inoculum improved plant development and increased the potassium content of the plant tissue as well as its yield. In the potato crop, variety Atlantic showed a reduction in the incidence of late blight and an increase in the most valued commercial calibers, in addition to an increase in yield, with the use of the tested inoculum. Cultivar Ágata exhibited a marked reduction in tuber defects with the use of the inoculum in the plants.

\section{Acknowledgments}

This research was supported by the Research Foundation of the State of São Paulo (FAPESP 2019/22765-5).

\section{References}

Adesemoye, A. O., Torbert, H. A., \& Kloepper, J. W. (2009). Plant growth-promoting rhizobacteria allow reduced application rates of chemical fertilizers. Microbial Ecology, 58, 921-929. https://doi.org/10.1007/s00248-009-9531-y.

Aguiar, A. T. E., Gonçalves, C., Paterniani, M. E. A. G. Z., Tucci, M. L. S., \& Castro, C. E. F. (2014). Instruções agrícolas para as principais culturas econômicas. ( $7^{\mathrm{a}}$. ed.) rev. e atual. Instituto Agronômico, Campinas, p. 452 (Boletim IAC, n.200)

Andrews, J. H. (1992). Biological control in the phyllosphere. Annual review of phytopathology, 30, 603-35. https://doi.org/10.1146/annurev.py.30.090192.003131.

Bakhshandeh, E., Gholamhosseini, M., Yaghoubian, Y., \& Pirdashti, H. (2020). Plant growth promoting microorganisms can improve germination, seedling growth and potassium uptake of soybean under drought and salt stress. Plant Growth Regulation, 90 (1), 123-136. 10.1007/s10725-019-00556-5.

Bakker, M. G., Manter, D. K., Sheflin, A. M., Weir, T. L., \& Vivanco, J. M. (2012). Harnessing the rhizosphere microbiome through plant breeding and agricultural management. Plant and Soil, 360, 1-13. https://doi.org/10.1007/s11104-012-1361-x.

Balen, A. B., Lange, A., Cavalli, E., Santos, P. H. Dos., \& Cavalli, C. (2015). XXV Congresso Brasileiro de Ciência do Solo. Aplicação de Fertilizante Foliar 
na Cultura da Soja.

Banerjee, A., Bareh, D. A., \& Joshi, S. R. (2017). Native microorganisms as potent bioinoculants for plant growth promotion in shifting agriculture (Jhum) systems. Journal of Soil Science and Plant Nutrition, 17 (1), 127-140. https://doi.org/10.4067/S0718-95162017005000010.

Bell, T. H., Yergeau, E., Martineau, C., Juck, D., Whyte, L. G., \& Greer C. W. (2011). Identification of nitrogen-incorporating bacteria in petroleumcontaminated arctic soils by using [15N]DNA-based stable isotope probing and pyrosequencing. Applied and Environmental Microbiology, 77 (12), 41634171. https://doi.org/10.1128/AEM.00172-11.

Bender, S. F., Wagg, C., \& Van Der Heijden, M. G.A. (2016). An Underground Revolution: Biodiversity and Soil Ecological Engineering for Agricultural Sustainability. Trends in Ecology and Evolution, 31(6), 440-452 https://doi.org/10.1016/j.tree.2016.02.016.

Bloemberg, G. V., \& Lugtenberg, B. J. J. (2001). Molecular basis of plant growth promotion and biocontrol by rhizobacteria. Current Opinion in Plant Biology, 4(4), 343-50. https://doi.org/10.1016/S1369-5266(00)00183-7.

Boddey, R. M., \& Dobereiner, J. (1995). Nitrogen fixation associated with grasses and cereals: Recent progress and perspectives for the future. Fertilizer Research, 42, 241-250. https://doi.org/10.1007/BF00750518.

Duarte, H. S. S. (2009). Resistência de cultivares de batata à requeima. Dissertação: mestrado em fitopatologia, Viçosa: UFV, p.61

Filgueira, F. A. R. (2008). Novo manual de olericultura: Agrotecnologia moderna na produção e comercialização de hortaliças. Viçosa: UFV, p. 402.

Hayat, R., Ali, S., Amara, U., Khalid, R., \& Ahmed, I. (2010). Soil beneficial bacteria and their role in plant growth promotion: A review. Annals of Microbiology, 60 (4), 579-598. https://doi.org/10.1007/s13213-010-0117-1.

$\mathrm{Hu}$, X., Chen, J., \& Guo, J. (2006). Two phosphate- and potassium-solubilizing bacteria isolated from Tianmu Mountain, Zhejiang, China. World Journal of Microbiology and Biotechnology, 22, (9), 983-990. https://doi.org/10.1007/s11274-006-9144-2.

Irikiin, Y., Nishiyama, M., Otsuka, S., \& Senoo, K. (2006). Rhizobacterial community-level, sole carbon source utilization pattern affects the delay in the bacterial wilt of tomato grown in rhizobacterial community model system. Applied Soil Ecology, 34(1), 27-32. https://doi.org/10.1016/j.apsoil.2005.12.003.

Kaminsky, L. M., Trexler, R. V., Malik, R. J., Hockett, K. L., \& Bell, T. H. (2019). The Inherent Conflicts in Developing Soil Microbial Inoculants. Trends in Biotechnology, 37 (2), 140-151. 10.1016/j.tibtech.2018.11.011.

Li, S. S., Zhu, A., Benes, V., Costea, P. I., Hercog, R., Hildebrand, F., Huerta-Cepas, J., Nieuwdorp, M., Salojärvi, J., Voigt, A. Y., Zeller, G., Sunagawa, S., De Vos, W. M., \& Bork, P. (2016). Durable coexistence of donor and recipient strains after fecal microbiota transplantation. Science, 352(6285), 586-589. https://doi.org/10.1126/science.aad8852.

Canteri, M. G., Althaus, R. A., Filho, J. S. V., Giglioti, E. A., \& Godoy, C. V. SASM-AGRI - Sistema para análise e separação de médias em experimentos agrícolas pelos métodos scott-knott, tukey e duncan. (2001). Revista Brasileira de Agrocomputação, 1, 18-24. https://doi.org/10.1016/j.aop.2019.05.003.

Marulanda, A., Barea, J. M., \& Azcón, R. (2009). Stimulation of plant growth and drought tolerance by native microorganisms (AM Fungi and bacteria) from dry environments: Mechanisms related to bacterial effectiveness. Journal of Plant Growth Regulation, 28, 115-124. https://doi.org/10.1007/s00344-009-90796.

Masood, S., Zhao, X. Q., \& Shen, R. F. (2019). Bacillus pumilus increases boron uptake and inhibits rapeseed growth under boron supply irrespective of phosphorus fertilization. AoB PLANTS, 11 (4), 1-10. https://doi.org/10.1093/aobpla/plz036.

Maurya, B. R., Meena, V. S., \& Meena, O. P. (2014). Influence of inceptisol and alfisol's potassium solubilizing bacteria (KSB) isolates on release of k from waste mica. Vegetos, 27(1), 181-187. https://doi.org/10.5958/j.2229-4473.27.1.028.

May, A., Coelho, L. F., Pedrinho, A., Batista, B. D., Mendes, L. W., Mendes, R., Morandi, M. A. B., Barth, G., Viana, R. S., \& Vilela, E. S. D. (2021). The use of indigenous bacterial community as inoculum for plant growth promotion in soybean cultivation. Archives of Agronomy and Soil Science, 00, 1-16. $10.1080 / 03650340.2021 .1964017$.

Meena, K. K., Sorty, A. M., Bitla, U. M., Choudhary, K., Gupta, P., Pareek, A., Singh, D. P., Prabha, R., Sahu, P. K., Gupta, V. K., Singh, H. B., Krishanani, K. K., \& Minhas, P. S. (2017). Abiotic stress responses and microbe-mediated mitigation in plants: The omics strategies. Frontiers in Plant Science, 8, 1-25. https://doi.org/10.3389/fpls.2017.00172.

Mendes, L. W., Tsai, S. M., Navarrete, A. A., De Hollander, M., Van, V. J. A., \& Kuramae, E. E. (2015). Soil-Borne Microbiome: Linking Diversity to Function. Microbial Ecology, 70(1), 255-265. https://doi.org/10.1007/s00248-014-0559-2.

Mo, B., \& Lian, B. (2011). Interactions between Bacillus mucilaginosus and silicate minerals (weathered adamellite and feldspar): Weathering rate, products, and reaction mechanisms. Chinese Journal of Geochemistry, 30(2), 187-192. https://doi.org/10.1007/s11631-011-0500-z.

Naik, K., Mishra, S., Srichandan, H., Singh, P. K., \& Sarangi, P. K. (2019). Plant growth promoting microbes: Potential link to sustainable agriculture and environment. Biocatalysis and Agricultural Biotechnology, 21, 1-12. 10.1016/j.bcab.2019.101326.

Oliveira, C. O., Pinto, C. C., Garcia, A., Bettiol, J. V. T., Sá, M. E. D., \& Lazarini, E. (2017). Production of soybean seeds enriched with molybdenum. Revista Ceres, 64, 282-290.

Parmar, P., \& Sindhu, S. S. (2013). Potassium Solubilization by Rhizosphere Bacteria: Influence of Nutritional and Environmental Conditions. Journal of Microbiology Research, 3(1), 25-31. 10.5923/j.microbiology.20130301.04.

Pillay, V. K., \& Nowak, J. (1997). lnoculum density, temperature, and genotype effects on in vitro growth promotion and epiphytic and endophytic colonization of tomato (Lycopersicon esculentum L.) seedlings inoculated with a pseudomonad bacterium. Canadian Journal of Microbiology, 43, 354-361. 
Research, Society and Development, v. 10, n. 12, e225101220351, 2021

(CC BY 4.0) | ISSN 2525-3409 | DOI: http://dx.doi.org/10.33448/rsd-v10i12.20351

Qiu, Z., Egidi, E., Liu, H., Kaur, S., \& Singh, B. K. (2019). New frontiers in agriculture productivity: Optimised microbial inocula and in situ microbiome engineering. Biotechnology Advances, 37(6), 1-11. 10.1016/j.biotechadv.2019.03.010.

Singh, M., Awasthi, A., Soni, S. K., Singh, R., Verma, R. K., \& Kalra, A. (2015). Complementarity among plant growth promoting traits in rhizospheric bacterial communities promotes plant growth. Scientific Reports, 5, 1-8. https://doi.org/10.1038/srep15500.

Sturz, A. V. (1995). The role of endophytic bacteria during seed piece decay and potato tuberization. Plant and Soil, 175(2), 257-263. https://doi.org/10.1007/BF00011362.

Tabassum, B., Khan, A., Tariq, M., Ramzan, M., Iqbal K., Muhammad S., Shahid, N., \& Aaliya, K. (2017). Bottlenecks in commercialisation and future prospects of PGPR. Applied Soil Ecology, 121, 102-117. 10.1016/j.apsoil.2017.09.030.

Töfoli, J. G., Domingues, R. J., \& Ferrari, J. T. (2019). Doenças fúngicas de solo na cultura da batata: sintomas, etiologia e manejo. O Biológico, 81(1), 1-24. https://doi.org/10.31368/1980-6221v81a10017.

Trentin, R., Heldwein, A. B., Streck, N. A., Trentin, G., \& Da Silva, J. C. (2013). Subperíodos fenológicos e ciclo da soja conforme grupos de maturidade e datas de semeadura. Pesquisa Agropecuaria Brasileira, 48(7), 703-713. https://doi.org/10.1590/S0100-204X2013000700002.

Wei, Z., Yang, T., Friman, V. P., Xu, Y., Shen, Q., \& Jousset, A. (2015). Trophic network architecture of root-associated bacterial communities determines pathogen invasion and plant health. Nature Communications, 6, 1-9. https://doi.org/10.1038/ncomms9413.

Wubs, E. R. J., Van D. P., Wim H., Bosch, M., \& Bezemer, T. M. (2016). Soil inoculation steers restoration of terrestrial Ecosystems. Nature Plants, 2, 1-5. https://doi.org/10.1038/NPLANTS.2016.107.

Yang, W., Xu, X., Li, Y., Wang, Y., Li, M., Wang, Y., Ding, X., \& Chu, Z. (2016). Rutin-mediated priming of plant resistance to three bacterial pathogens initiating the early SA signal pathway. PLOS ONE, 11(1), 1-15. https://doi.org/10.1371/journal.pone.0146910. 